Provided for non-commercial research and education use. Not for reproduction, distribution or commercial use.

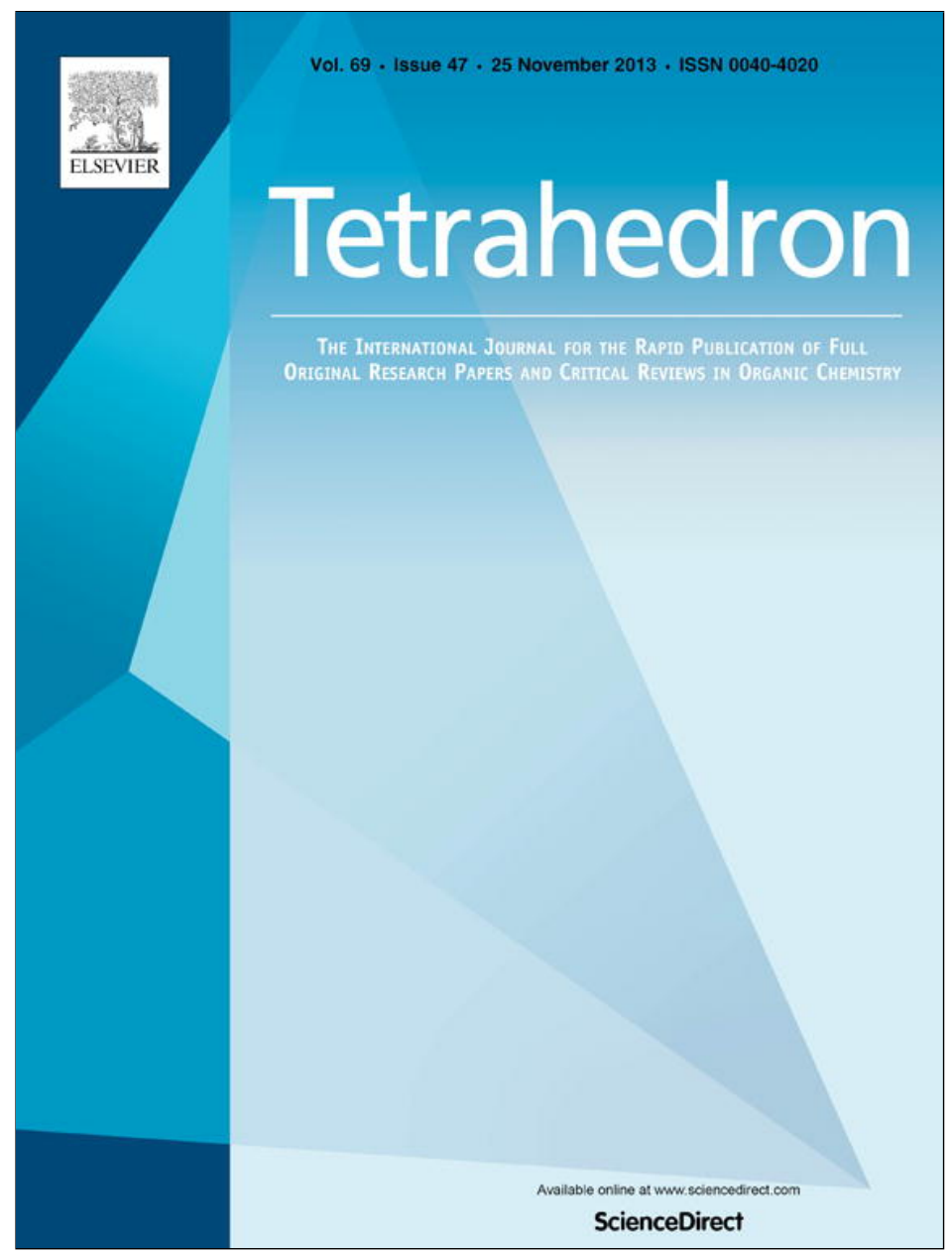

This article appeared in a journal published by Elsevier. The attached copy is furnished to the author for internal non-commercial research and education use, including for instruction at the authors institution and sharing with colleagues.

Other uses, including reproduction and distribution, or selling or licensing copies, or posting to personal, institutional or third party websites are prohibited.

In most cases authors are permitted to post their version of the article (e.g. in Word or Tex form) to their personal website or institutional repository. Authors requiring further information regarding Elsevier's archiving and manuscript policies are encouraged to visit:

http://www.elsevier.com/authorsrights 


\title{
Ethyl 2,2-bis(4-methylphenylsulfonamido)acetate to aromatic $\alpha$-amino acids: stable substrates for catalytic arylation reactions
}

\author{
Carolina S. Marques ${ }^{\mathrm{a}, \mathrm{b}}$, Anthony J. Burke ${ }^{\mathrm{a}, \mathrm{b}, *}$ \\ a Department of Chemistry and Centro de Química de Évora, Universidade de Évora, Rua Romão Ramalho, 59, 7000 Évora, Portugal

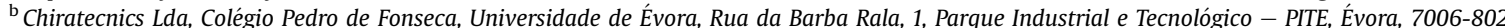 \\ Évora, Portugal
}

\section{A R T I C L E I N F O}

\section{Article history:}

Received 10 June 2013

Received in revised form 12 September 2013

Accepted 17 September 2013

Available online 24 September 2013

\section{Keywords:}

Arylation

Catalysis

Arylboronic acids

Amino acids

$\alpha, \alpha$-Ditosylamino esters

\begin{abstract}
A B S T R A C T
This paper reports the development of a novel methodology for the catalytic synthesis of aromatic $\alpha$ amino acids, which involves the addition of aryl-organoboron reagents to $\alpha, \alpha$-ditosylamino esters derived from ethyl glyoxylate, using transition metal catalysts, like Rh and Pd. A library of $\alpha$-amino esters (12 with Pd and 8 with Rh), was synthesized with moderate to excellent yields. A highest enantioselectivity of $30 \%$ ee was obtained using Hayashi's ligand. This method was applied to the synthesis of phenylglycine.
\end{abstract}

(c) 2013 Elsevier Ltd. All rights reserved.

\section{Introduction}

Unnatural or non-proteinogenic $\alpha$-amino acids, ${ }^{1}$ are ubiquitous in all living organisms on earth and perhaps the most important family of carbonyl compounds in biological systems. Due to both their structural diversity and functional versatility, their scope of application is huge, covering the field of organic and medicinal chemistry, biology and agrochemical science. ${ }^{2}$ For instance, numerous therapeutically relevant compounds, ${ }^{3}$ such as Amoxicillin (an antibacterial agent) or Enalapril (an antihypertensive agent) consist of this functionality (see Fig. 1). They can be used as well as building blocks, in natural product synthesis, or as chiral auxiliaries, catalysts or ligands. ${ }^{4}$

Although enzymatic synthesis and chiral resolutions are viable methods for the production of naturally occurring chiral $\alpha$-amino acids, ${ }^{5}$ they are often not useful for synthesizing non-natural Damino acids or amino acids with non-natural side chains. The formation of diastereomeric salts of optically impure amino acid mixtures, ${ }^{6}$ followed by chiral resolution is time consuming and therefore expensive, and thus a need to invest in alternative synthetic routes was deployed. Due to their importance, a variety of general methods for the synthesis have been described in the

\footnotetext{
* Corresponding author. Tel.: +351 266745 310; fax: +351 266745 303; e-mail addresses: ajb@chiratecnics.com, ajb@dquim.uevora.pt (A.J. Burke).
}

literature, ${ }^{4}$ amongst these, there is the Strecker synthesis, which relies on the stereoselective addition of carboxylate synthons across $\mathrm{C}=\mathrm{N}$ bonds, ${ }^{4,7}$ the Knowles Monsanto asymmetric hydrogenation of a di-dehydro amino $\mathrm{acid}^{8}$ (an efficient industrial process to synthesize L-Dopa (see Fig. 1 ), and the Corey-Link reaction, ${ }^{9}$ that involves asymmetric addition of hydride to a ketone precursor.
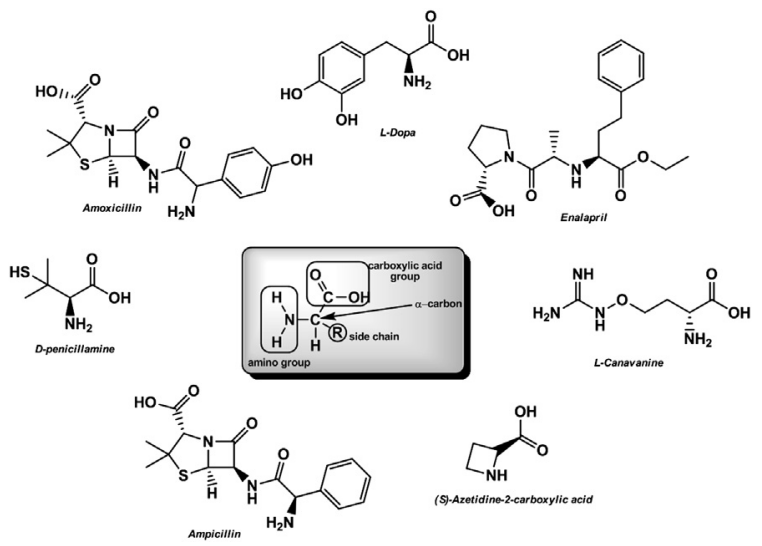

Fig. 1. Examples of important compounds containing the $\alpha$-amino acid scaffold; $L-$ Dopa: anti-Parkinson therapeutic agent; Enalapril: antihypertensive therapeutic agent; L-Canavanive: anti-predatory agent in plants; (S)-Azetidine-2-carboxylic acid: an analogue of proline; Ampicillin and Amoxicillin: antibacterial therapeutic agents; D-Penicillamine: anti-rheumatic therapeutic agent. 
There are, of course, many other routes to chiral $\alpha$-amino acids, such as the addition of organic nucleophiles to $\alpha$-imino esters or enolates, a methodology that has emerged as one of the most promising routes to optically enriched $\alpha$ - and $\beta$-amino acid derivatives, including $\beta$-lactams. ${ }^{10}$ Sodeoka and co-workers reported the first example of an asymmetric addition of enol silyl ethers to $\alpha$ imino esters employing a hydrated Pd(II)-based chiral Lewis acid system. ${ }^{11}$ This so called Mannich-type reaction led to optically active $\gamma$-oxo- $\alpha$-amino esters with modest to high enantioselectivities (45-95\% yield and 53-90\% ee). Later on, Kobayashi's group ${ }^{12}$ reported an improvement of this methodology using $\mathrm{N}$-acylimine esters with enol silanes and $\mathrm{Cu}(\mathrm{II})$ catalysts to produce $\mathrm{N}$-acylated amino acids with high yields and high enantioselectivities (77-97\% yield and 90-97\% ee) under smooth reaction conditions. Transition metal-phosphane complexes were applied as catalysts by Lectka group $^{13}$ for the catalytic asymmetric alkylation of $\alpha$-imino esters and $\mathrm{N}, \mathrm{O}$-acetals with enol silanes, ketene acetals, alkenes and allylsilanes. Jorgensen and co-workers ${ }^{14}$ and Johannsen, ${ }^{15}$ independently applied the combination of $\mathrm{CuPF}_{6}$ and $(R)$-tol-BINAP in the enantioselective addition of imines to electron-rich aromatic compounds, affording protected optically active $\alpha$-aryl $\alpha$-amino esters in good to high yields and with high regioselectivity and enantioselectivity (up to $98 \%$ ee). The limitation with this approach is the restriction to electron-rich aromatic compounds, although the avoidance of often troublesome enol silyl ethers or silyl ketene acetals, is the main advantage of this methodology.

Our group is currently engaged in the development of catalytic reactions for carbon-carbon bond formation using imine substrates and aldehydes, organoboron reagents and transition metal catalysts. ${ }^{16}$ We have now developed a new process that affords aryl $\alpha$-amino acids via arylation of di- $\alpha, \alpha$-tosylamino esters with arylboronic acids and transition metal catalysts.

\section{Results and discussion}

Using the same methodology applied previously in the synthesis of imine derivatives, ${ }^{16 \mathrm{c}}$ the 2,2-bis(4-methylphenylsulfonamido) acetate ester (2) was synthesized from commercially available ethyl glyoxylate (1), through the addition of $p$-toluenesulfonamide, in toluene, with a catalytic quantity of the Lewis acid $\mathrm{BF}_{3} \cdot \mathrm{Et}_{2} \mathrm{O}$, by refluxing in a Dean-Stark trap (Scheme 1 ). The di- $\alpha, \alpha$-tosylamino ester (2) has already been prepared by Lectka's group ${ }^{17}$ and was obtained in $20 \%$ yield, using equimolar amounts of ethyl glyoxylate (1) and $p$-toluenesulfonamide.

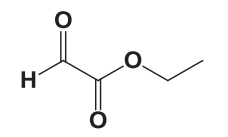

(1)

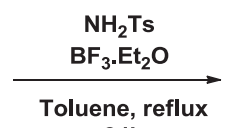

$24 \mathrm{~h}$

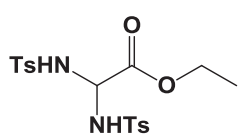

(2)
Scheme 1. Synthesis of $N, N$-di-p-toluenesulfonylglycine ester (2) using ethyl glyoxylate (1) and $p$-toluenesulfonamide $\left(\mathrm{NH}_{2} \mathrm{Ts}\right)$.

Great advances have been made in the field of $\alpha$-arylation of carbonyl compounds catalyzed by transition metal catalysts. ${ }^{18}$ The nucleophilic aromatic substitution of enolates with aryl halides ${ }^{19}$ and the transition-metal-catalyzed $\alpha$-arylation of carbonyl compound $s^{20}$ are the two main methods for efficient construction of quaternary centres with good enantioselectivity. ${ }^{21}$ As far as we know, the arylation of di- $\alpha, \alpha$-tosylamino esters-which are activated aminal compounds-has never been reported in the literature, so we decided to develop the catalytic arylation of ditosylamino ester (2). ${ }^{22}$ Gratifyingly we observed that the ditosylamine ester (2) could be converted to the desired $\mathrm{N}$-tosylamine ester (3a) in $38 \%$ yield, when treated with phenylboronic acid and $\mathrm{Pd}(\mathrm{OAc})_{2} /$ bpy (Table 1$)$. Despite the moderate yield, we were encouraged by the result and proceeded with screening a plethora of other boronic acids, using the catalytic system described above. The advantage of using these arylating agents is that they are commercially available from a number of suppliers, easy to handle and have a low toxicity profile. ${ }^{23}$ The results can be seen in Table 1. The principle advantage of this method appears to be the avoidance of imine substrates that undergo facile hydrolysis under the reaction conditions of their arylation. ${ }^{16 \mathrm{c}}$

\section{Table 1}

Screening of arylboronic acid derivatives to afford the $\alpha$-amino ester derivatives (3) with Pd catalysts, using the di-tosylamine ester (2) as substrate

\begin{tabular}{|c|c|c|c|}
\hline & $+\operatorname{ArB}$ ( & Dioxane, $100^{\circ} \mathrm{C}$ & (3) \\
\hline Entry & & $\alpha$-Amino ester (3) & Yield $/ \%^{b}$ \\
\hline 1 & $\mathrm{C}_{6} \mathrm{H}_{5}$ & $\mathbf{a}$ & 38 \\
\hline 2 & 2-Naph & b & 28 \\
\hline 3 & $2-\mathrm{CH}_{3} \mathrm{OC}_{6} \mathrm{H}_{4}$ & c & 58 \\
\hline 4 & $4-\mathrm{ClC}_{6} \mathrm{H}_{4}$ & d & 35 \\
\hline 5 & $3-\mathrm{CH}_{3} \mathrm{OC}_{6} \mathrm{H}_{4}$ & $\mathbf{e}$ & 56 \\
\hline 6 & $3-\mathrm{AcC}_{6} \mathrm{H}_{4}$ & f & 61 \\
\hline 7 & 1-Naph & $\mathbf{g}$ & 79 \\
\hline 8 & $4-\mathrm{FC}_{6} \mathrm{H}_{4}$ & h & 45 \\
\hline 9 & 3- $\mathrm{PhCH}_{2} \mathrm{OC}_{6} \mathrm{H}_{4}$ & $\mathbf{i}$ & 30 \\
\hline 10 & $3-\mathrm{HOC}_{6} \mathrm{H}_{4}$ & $\mathbf{j}$ & 31 \\
\hline 11 & 3- $\mathrm{NH}_{2} \mathrm{C}_{6} \mathrm{H}_{4}$ & $\mathbf{k}$ & 37 \\
\hline 12 & $4-\mathrm{CH}_{3} \mathrm{OC}_{6} \mathrm{H}_{4}$ & 1 & 39 \\
\hline
\end{tabular}

${ }^{a}$ Reaction conditions: $\operatorname{Pd}(\mathrm{OAc})_{2}(5 \mathrm{~mol} \%)$, bpy $(10 \mathrm{~mol} \%)$, di- $\alpha, \alpha$-tosylamine ester (2) $(0.3 \mathrm{mmol}), \mathrm{ArB}(\mathrm{OH})_{2}(1.0 \mathrm{mmol})$ and dioxane $(2 \mathrm{ml})$ was used.

b Isolated yields after liquid chromatography.

The yields were moderate to good, showing good tolerance for the presence of both electron-donating and electron-withdrawing substituents in the phenyl ring of organoboron reagent. The best yield was obtained with 1-naphthylboronic acid (Table 1, entry 7). No significant difference was observed using an electron-donating or an electron-withdrawing group in the organoboron reagent, but apparently the reaction yield improved-as confirmed from literature precedent ${ }^{16 c, 24}$ - when an electron-withdrawing group was present (see Table 1, entries 6 and 8). No very significant differences in the yield were noted when either electron-donating or electronwithdrawing substituents were present in the ortho, meta or para positions of the aromatic ring (see Table 1), thus showing good tolerance for both electronic and steric effects. However in the case of Rh catalysis (vide infra) this is not the case, and is discussed below. We were also curious to check the scope of this reaction with aliphatic boronic acids. ${ }^{25}$ So, we decided to test three of these specific reagents: methylboronic acid, ethylboronic acid and 1dodecylboronic acid. Unfortunately the reactions didn't work, since only the aminal substrate (2) was recovered. The problem with these reactions in the context of Pd catalysis was that probably unnecessary side-reactions, such as homocoupling ${ }^{26}$ and basecatalyzed proto-deboration, ${ }^{27}$ ensued, with the inevitable consumption of the arylboronic acid derivatives. We tried to promote an asymmetric version of this reaction, using $(R, R)$-Me-DuPhos (Fig. 2) as chiral phosphane ligand, and other chiral ligands, such as oxazoline type and NHC type, applying the conditions previously developed by us ${ }^{16 a}$ but, this was unsuccessful and the yields were very poor, and thus further investigation was abandoned. At this point we decided to explore the use of Rh catalysts, for two reasons: i) to try and improve the yields, and ii) to develop chiral catalysts 


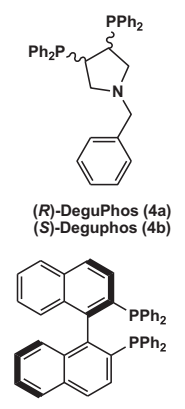

$(R)$-BINAP (7)
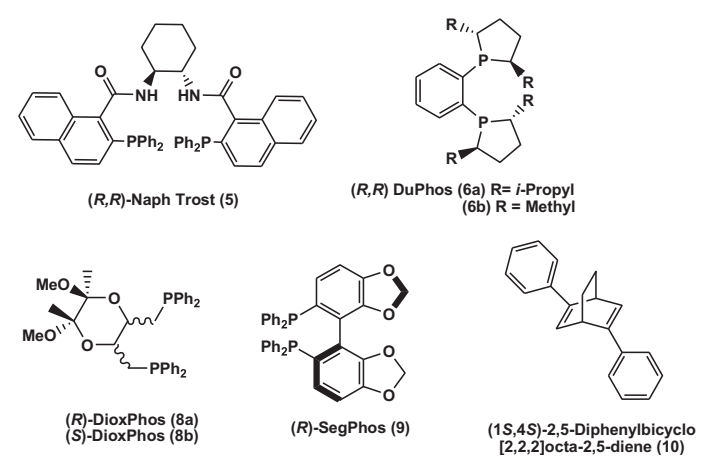

Fig. 2. Some of the chiral ligands that were screened in this study. Note: (6a), (6b), (7), $(\mathbf{8 a})$ and $(\mathbf{8 b})$ gave very low enantioselectivities ( $<5 \%$ ee).

that would lead to a successful asymmetric version of this reaction. Thus for this purpose $\mathrm{PPh}_{3}$ and a variety of chiral phosphane ligands, were investigated (Fig. 2). Only the best results are highlighted in Table 2 . We decided to use $[\mathrm{Rh}(\mathrm{COD}) \mathrm{OH}]_{2}$, as one of the catalyst precursors, because of its many interesting applications in the literature. ${ }^{28} \mathrm{Ru}$ was also investigated- $-\left[\mathrm{RuCl}_{2}\left(\eta^{6}-p \text {-cymene }\right)\right]_{2}$ with $(R, R)$-Me-DuPhos (6a) and Trost's ligand (5)-but the yield was very poor and the \% ee was not determined. In fact, this $\mathrm{Rh}(\mathrm{I})$ catalyst along with $(R, R)$-DeguPhos (4a) was already applied successfully by Ellman's group in the enantioselective addition of arylboronic acids to diphenylphosphinoyl imines. ${ }^{28 \mathrm{f}}$ We also screened the commercial chiral diene of Hayashi (10) (Fig. 2). ${ }^{29}$ As of yet we haven't established the configuration of the major enantiomer.

Table 2

Transformation of di-tosylamino ester (2) to arylamino ester (3a) using Rh catalysis $\underbrace{(2)}_{\text {NHTs }}+\mathrm{PhB}_{(\mathrm{OH})_{2}} \frac{\begin{array}{l}\text { Rh catalyst }(3 \mathrm{~mol} \%) \text {, } \\ \text { Ligand }(3.3 \mathrm{~mol} \%) \text {, }\end{array}}{55-100^{\circ} \mathrm{C}}$

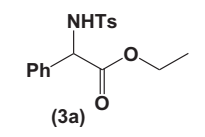

\begin{tabular}{llllll}
\hline Entry & $\mathrm{Rh}$ catalyst & Ligand & $\begin{array}{l}\text { Additive/solvent/temp } \\
\left({ }^{\circ} \mathrm{C}\right)\end{array}$ & $\begin{array}{l}\text { Time } \\
(\mathrm{h}) / \text { yield }(\%)^{\mathrm{a}}\end{array}$ & $\begin{array}{l}\mathrm{ee}^{\mathrm{b}} \\
(\%)\end{array}$ \\
\hline 1 & {$[\mathrm{Rh}(\mathrm{COD}) \mathrm{OH}]_{2}$} & $\mathrm{PPh}_{3}$ & $\mathrm{~K}_{3} \mathrm{PO}_{4} /$ dioxane/70 & $18(14)$ & n.a. \\
2 & {$[\mathrm{Rh}(\mathrm{COD}) \mathrm{OH}]_{2}$} & $\mathrm{PPh}_{3}$ & $\mathrm{NEt}_{3} /$ toluene/70 & $18(22)$ & n.a. \\
$3^{\mathrm{c}}$ & {$[\mathrm{Rh}(\mathrm{COD}) \mathrm{OH}]_{2}$} & $\mathrm{None}$ & $\mathrm{KHF}_{2} /$ dioxane/100 & $24(13)$ & n.a. \\
4 & {$[\mathrm{Rh}(\mathrm{COD}) \mathrm{Cl}]_{2}$} & $\mathrm{None}$ & $\mathrm{MgSO}_{4} /$ dioxane/80 & $23(22)$ & n.a. \\
5 & {$[\mathrm{Rh}(\mathrm{COD}) \mathrm{Cl}]_{2}$} & $(\mathbf{4 a})$ & $\mathrm{MeOH}^{2}$ dioxane/100 & $16(52)$ & 15 \\
$6^{\mathrm{c}}$ & {$[\mathrm{Rh}(\mathrm{COD}) \mathrm{Cl}]_{2}$} & $(\mathbf{4 a})$ & $\mathrm{KHF}_{2} /$ dioxane/80 & $17(96)$ & 15 \\
7 & {$[\mathrm{Rh}(\mathrm{COD}) \mathrm{Cl}]_{2}$} & $(\mathbf{4 a})$ & $\mathrm{KHF}_{2} /$ toluene/55 & $21(18)$ & 18 \\
$8^{\mathrm{d}}$ & {$[\mathrm{Rh}(\mathrm{COD}) \mathrm{OH}]_{2}$} & $(\mathbf{5})$ & $\mathrm{KHF}_{2} /$ dioxane/100 & $24(99)$ & $<5$ \\
$9^{\mathrm{d}}$ & {$[\mathrm{Rh}(\mathrm{COD}) \mathrm{OH}]_{2}$} & $(\mathbf{7})$ & $\mathrm{KHF}_{2} /$ dioxane/100 & $24(94)$ & $<5$ \\
$10^{\mathrm{d}}$ & {$[\mathrm{Rh}(\mathrm{COD}) \mathrm{OH}]_{2}$} & $(\mathbf{9})$ & $\mathrm{KHF}_{2} /$ dioxane/100 & $24(58)$ & 13 \\
$11^{\mathrm{d}}$ & {$[\mathrm{Rh}(\mathrm{COD}) \mathrm{OH}]_{2}$} & $(\mathbf{1 0})$ & $\mathrm{KHF}_{2} /$ dioxane/100 & $24(30)$ & 12 \\
\hline
\end{tabular}

n.a. not applicable.

${ }^{a}$ Isolated yields after liquid chromatography.

b As determined by HPLC with a chiral column.

c Reaction run with $\mathrm{KHF}_{2} 3 \mathrm{M}$ (aq solution).

d $0.8 \mathrm{mmol} \mathrm{KHF}_{2}$ was used.

The results were very interesting. What was immediately observed was that better yields than those achieved with Pd were obtained (e.g., 99\%, Table 2, entry 8 ). We found that generally the chiral ligands gave better yields than $\mathrm{PPh}_{3}$ (Table 2, entries 1 and 2) and in fact, when no ligand was present, a yield comparable to that obtained with $\mathrm{PPh}_{3}$ was obtained (Table 2, entries 3 and 4). The highest enantioselectivity obtained was $30 \%$ ee using Hayashi's ligand (10) and the best with phosphanes was $16 \%$ ee recorded with (4b), but, unfortunately the yields were very low. Although, it seems that the use of $\mathrm{KHF}_{2}$ as base gave the best yields.
As the enantioselectivities were lower than what we expected, we decided to establish if there was any racemization taking place. On performing the reactions with $\mathrm{D}_{2} \mathrm{O}$ in the reaction medium, it was established by ${ }^{1} \mathrm{H}$ NMR that there was no incorporation of deuterium in the $\alpha$-position. The reaction was also monitored over a $24 \mathrm{~h}$ period, and no deterioration in the reaction enantioselectivity was observed from the 1st to the 24th hour. These experiments show that racemization was not the cause of the low enantioselectivities. Based on our previous experience, ${ }^{16 \mathrm{~d}}$ it appears that during the catalytic cycle there is a likely possibility of exchange of the chiral ligand with the imine substrate, thus eliminating or diminishing greatly the asymmetric induction.

HPLC analysis has shown the presence of the imine precursor to (2) in some of the chromatograms. This seems to support the conjecture that (2) undergoes elimination of $p$-tosylsulfonamine during the catalytic reaction.

We decided on the basis of the good yields achieved with $(R, R)$ DeguPhos (4a) and $[\mathrm{Rh}(\mathrm{COD}) \mathrm{OH}]_{2}$ in this initial screening study (99\% yield, Table 2, entry 8 ) to access the reaction scope using a variety of arylboronic acids (Table 3 ).

Table 3

Transformation of di-tosylamino ester (2) to arylamino esters (3) using Rh catalysis $[\mathrm{Rh}(\mathrm{COD}) \mathrm{OH}]_{2} 3 \mathrm{~mol} \%$

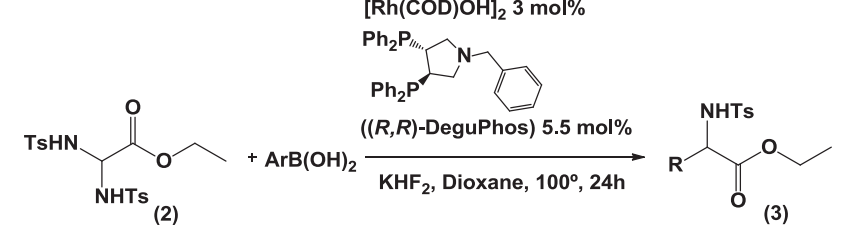

\begin{tabular}{lllc}
\hline Entry $^{\mathrm{a}}$ & & $\alpha$-Amino ester (3) & Yield/\% \\
\hline 1 & $\mathrm{C}_{6} \mathrm{H}_{5}$ & $\mathbf{a}$ & 99 \\
$2^{\mathrm{c}}$ & $\mathrm{C}_{6} \mathrm{H}_{5}$ & $\mathbf{a}$ & 13 \\
$3^{\mathrm{d}}$ & $\mathrm{C}_{6} \mathrm{H}_{5}$ & $\mathbf{a}$ & 74 \\
$4^{\mathrm{e}}$ & $\mathrm{C}_{6} \mathrm{H}_{5}$ & $\mathbf{a}$ & 34 \\
5 & $2-\mathrm{Naph}^{\mathrm{e}}$ & $\mathbf{b}$ & 74 \\
6 & $2-\mathrm{CH}_{3} \mathrm{OC}_{6} \mathrm{H}_{4}$ & $\mathbf{c}$ & 83 \\
7 & $4-\mathrm{ClC}_{6} \mathrm{H}_{4}$ & $\mathbf{d}$ & 61 \\
8 & $3-\mathrm{CH}_{3} \mathrm{OC}_{6} \mathrm{H}_{4}$ & $\mathbf{e}$ & 0 \\
9 & $3-\mathrm{AcC}_{6} \mathrm{H}_{4}$ & $\mathbf{f}$ & 0 \\
10 & $1-\mathrm{Naph}_{1}$ & $\mathbf{g}$ & 99 \\
11 & $4-\mathrm{FC}_{6} \mathrm{H}_{4}$ & $\mathbf{h}$ & 0 \\
12 & $3-\mathrm{PhCH}_{2} \mathrm{OC} \mathrm{H}_{4}$ & $\mathbf{i}$ & 25 \\
13 & $3-\mathrm{HOC}_{6} \mathrm{H}_{4}$ & $\mathbf{j}$ & 0 \\
14 & $3-\mathrm{NH}_{2} \mathrm{C}_{6} \mathrm{H}_{4}$ & $\mathbf{k}$ & 17 \\
15 & $4-\mathrm{CH}_{3} \mathrm{OC}_{6} \mathrm{H}_{4}$ & $\mathbf{1}$ & 61 \\
\hline
\end{tabular}

${ }^{a}$ Reaction conditions: [Rh(COD)OH] $]_{2}(1.5 \mathrm{~mol} \%),(R)$-DeguPhos (3.3 mol \%), ditosylamine ester (2) $(0.12 \mathrm{mmol}), \mathrm{ArB}(\mathrm{OH})_{2}(0.4 \mathrm{mmol}), \mathrm{KHF}_{2}(0.8 \mathrm{mmol})$ and dioxane $(2 \mathrm{ml})$ was used.

b Isolated yields after liquid chromatography. All the products were obtained in racemic form, as determined by HPLC with a chiral column.

${ }^{c}$ Reaction made without $(R, R)$-DeguPhos.

${ }^{\mathrm{d}}$ Reaction run with $\mathrm{KHF}_{2} 3 \mathrm{M}$ (aq solution). Note: the ee values have not been included due to being too low.

e Reaction runs without additive.

Starting with the simple phenylboronic acid, the reaction gave the expected $\alpha$-amine ester product (3a) with full conversion (99\% yield, Table 3 , entry 1 ). To test the reaction conditions we decided to run the same reaction without ligand, in $\mathrm{H}_{2} \mathrm{O}$ and without additive (Table 3, entries 2, 3 and 4, respectively). The importance of the diphosphane ligand on the activity of the active catalyst was clearly shown (compare entries 1 and 2, Table 3 ), as well as the importance of an inorganic additive $\left(\mathrm{KHF}_{2}\right)$, already used with success in this reaction type ${ }^{30}$ (compare entries 1 and 4 , Table 3 ). Since $\mathrm{KHF}_{2}$ under aqueous conditions can react with the organoboronic acids to generate the more reactive potassium organotrifluoroborates ${ }^{30 c}$ we investigated the direct use of this type of reagent on the 
outcome of the reaction (Table 3, entry 3). The yield decreased from $99 \%$ to $34 \%$ (Table 3, compare entries 1 and 3). This was undoubtedly due to hydrolysis of the activated imine. ${ }^{16 a, c}$

Motivated by the excellent result obtained with this optimized method (Table 3, entry 1 ), in order to establish the scope of this method, we conducted a screening of a range of arylboronic acids. The yield increased in particular when a naphthylboronic acid was used (Table 3, entries 5 and 10). Almost all of the organoboron reagents containing an electron-withdrawing group in the phenyl ring were inactive (Table 3 , entries $8,9,11$ and 13 ).

In the case of Rh catalysis, it seems that the catalyst is sensitive to electronic effects in the aromatic ring of the organoboron reagent, as the use of electron-donating substituents in the ortho and para positions gave good yields, (see Table 3, entries 5, 6, 10 and 15). But, there was no reaction when strong inductively electronwithdrawing groups were present in the meta position of the arylboronic acid (Table 3, entries 8,9 and 13) and when a p-fluoro group was present (Table 3, entry 11).

No products were obtained when aliphatic boronic acids were used (methylboronic acid, ethylboronic acid and 1-dodecylboronic acid). It seems that an aromatic system needs to be present.

Upon finding the optimal conditions for HPLC analysis, we were very disappointed to find very low enantioselectivities of the order $<5-10 \%$ ee for all the compounds synthesized. We then screened a plethora of commercial diphosphane chiral ligands, to try and improve the reaction enantioselectivity. Well known ligands, ${ }^{16 a, c}$ such as BINAP (7), DuPhos (6) or Trost-diphosphane (5) (see Fig. 2) were all screened, but no outstanding improvements were achieved (a maximum of $15 \%$ ee was the best obtained using the commercial ligand $(R, R)$-naphthyl Trost-diphosphane (5), Fig. 2).

In order to establish an efficient route to obtaining the free $\alpha$ amino acids, the amine activating group needs to be removed. In fact, this has previously proved to be particularly troublesome with these systems. ${ }^{31}$ We thus developed a simple reaction process to phenylglycine (11) (Scheme 2)-an important motif in the antibiotic Ampicillin (see Fig. 1), using an aqueous solution of $\mathrm{NaOH}$ in THF (Scheme 2). ${ }^{32}$ Obviously, this method of deprotection will probably lead to the racemic amino acid product when the substrate is optically pure, however, for the purpose of at least accessing the amino acid product, we successfully demonstrated the applicability of this method (Scheme 2).

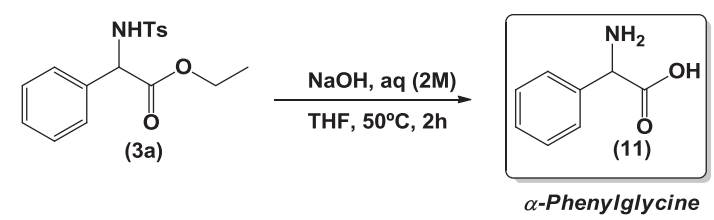

Scheme 2. Conversion to the racemic unnatural $\alpha$-amino acid derivatives. Synthesis of (rac)- $\alpha$-phenylglycine.

We also discovered that by adding $\mathrm{K}_{2} \mathrm{CO}_{3}$ to the reaction medium during the arylation of the di-tosylamino ester (2), the tosyl group was removed after presumably the formation of the arylated ester product affording the amine ester product (12), in $72 \%$ yield (Scheme 3). We are currently further investigating the scope of this procedure.

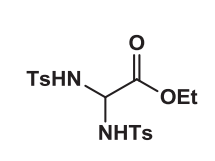

(2)

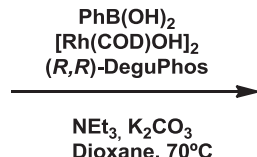

Dioxane, $70^{\circ} \mathrm{C}$

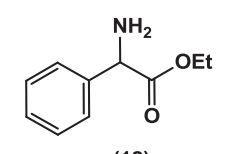

(12)
Scheme 3. One-pot arylation-amine deprotection protocol.

\section{Conclusions}

We have reported herein an alternative innovative method for the synthesis of $\alpha$-amino acid derivatives using stable 2,2-bis(4methylphenylsulfonamido)acetate ester (2). This new methodology utilizing arylboronic acids with transition metal catalysts, although not suitable yet-despite promising indications-for the synthesis of enantioenriched $\alpha$-aryl amino acids, afforded a diverse library of $\alpha$-amine ester products. On-going studies on the mechanism are currently underway, as well as studies at optimizing and improving the reaction enantioselectivity.

\section{Experimental section}

\subsection{General remarks}

All the reagents were obtained from Aldrich, Fluka and Acros. The commercial diphosphane ligands were obtained from either Strem Chemicals, or Aldrich, with the exception of the $(R, R)$-DeguPhos, $(R)$ and $(S)$-DioxPhos, which were obtained from ChiraTecnics Lda (Portugal). The solvents used were dried under current laboratory techniques. ${ }^{33}$ 1,4-Dioxane was distilled from $\mathrm{Na}$ and benzophenone. All the reagents applied in this work were used as received. All reactions with transition metals (Pd, Rh) were conducted under a nitrogen atmosphere. The di-tosylamino ester (2) was synthesized according to literature procedures. ${ }^{16}$ Column chromatography was carried out on silica gel (SDS, 70-200 $\mu \mathrm{m}$ ). Thin layer chromatography (TLC) was carried out on aluminium backed Kieselgel $60 \mathrm{~F}_{254}$ plates (Merck). Plates were visualized either by UV light or with phosphomolybdic acid in ethanol. The NMR analyses were recorded on a Bruker Avance instrument ( $400 \mathrm{MHz}$ ) using $\mathrm{CDCl}_{3}$ as solvent and the signal from the residual $\mathrm{CHCl}_{3}$ used as an internal standard. High performance liquid chromatographic (HPLC) analysis was performed on an Agilent 1100 series instrument. The conditions used were: $p_{\max }=50$ bar; flux $=1 \mathrm{ml} / \mathrm{min}$; detector=wavelength light $(\lambda=230 \mathrm{~nm})$; eluent=hexane/isopropanol; column $=$ Chiralcel OD-H $(0.46 \mathrm{~cm} \times 25 \mathrm{~cm})$, fitted with a guard column composed of the same stationary phase. Mass spectra were recorded on either a Waters-Micromass MaldiTOF or MicroTOF Focus (Bruker Daltonics) by using the TOF (time-of-light) technique.

\section{2. $\alpha, \alpha$-Ditosylamine ester synthesis}

4.2.1. Synthesis of ethyl 2-(tosylimino)acetate substrate (2). ${ }^{17}$ By using a Dean-Stark trap to facilitate water removal, $\mathrm{BF}_{3} \cdot \mathrm{Et}_{2} \mathrm{O}$ $\left(1.6 \times 10^{-3} \mathrm{~mol}\right)$ was added (through a syringe) to a refluxing solution of ethyl glyoxylate (1) (50\% in toluene, $0.1 \mathrm{~mol}$ ) and $p$-toluenesulfonamide $(0.1 \mathrm{~mol})$ in toluene $(200 \mathrm{ml})$. The mixture was kept under reflux until the theoretical amount of water $(0.1 \mathrm{~mol})$ was collected. The solution was then cooled to room temperature and a white solid precipitated. The mixture was filtrated and the white solid washed with toluene. After drying under reduced pressure, we obtained the desired product in $32 \%$ yield. Mp: $178-189^{\circ} \mathrm{C}$ (mp lit.: $\left.178-180^{\circ} \mathrm{C}\right)$; FTIR $\left(\mathrm{cm}^{-1}\right)$ : $1200,1344,1597,1728,3257 .{ }^{1} \mathrm{H}$ NMR $\left(400 \mathrm{MHz}, \mathrm{CDCl}_{3}+\mathrm{DMSO}_{6}\right) \delta: 1.00\left(\mathrm{t}, \mathrm{CH}_{3}, 3 \mathrm{H}\right), 2.35\left(\mathrm{~s}, \mathrm{CH}_{3} \mathrm{Ts}, 3 \mathrm{H}\right)$, 3.84-3.89 (q, $\left.\mathrm{CH}_{2}, 2 \mathrm{H}\right), 6.97-6.99$ (d, NH, 2H), 7.17-7.19 (d, Ar, 2H), $7.62-7.64(\mathrm{~d}, \mathrm{HC}=\mathrm{N}, 1 \mathrm{H}) \mathrm{ppm} .{ }^{13} \mathrm{C}$ NMR $\left(100 \mathrm{MHz}, \mathrm{CDCl}_{3}+\mathrm{DMSO}-\right.$ $\left.d_{6}\right) \delta: 13.64,21.53,62.51,63.39,127.08,129.41,137.92,143.35$, $167.43 \mathrm{ppm}$. MS (ESI-TOF) $\mathrm{m} / \mathrm{z}$ : $256.07(\mathrm{M}+1)$. HPLC analysis [Chiralcel OD-H, hexane/2-propanol (95:5), flow rate $=1.0 \mathrm{ml} / \mathrm{min}$, $\lambda=230 \mathrm{~nm}]: t_{R}=11.3 \mathrm{~min}$.

\subsection{Catalytic reactions}

4.3.1. General procedure for the catalytic addition of boronic acids to ethyl 2,2-bis(4-methylphenylsulfonamido)acetate (2) using a Pd 
catalyst $^{22}$ (Table 1). 1,4-Dioxane $(2.0 \mathrm{ml})$ was added to a roundbottom flask containing $\mathrm{Pd}(\mathrm{OAc})_{2} \quad(5 \mathrm{~mol} \%)$, bpy ligand (10 $\mathrm{mol} \%$ ), the organoboron reagent $(1.0 \mathrm{mmol})$ and the 2,2-bis(4methylphenylsulfonamido)acetate $(2)(0.3 \mathrm{mmol})$ under nitrogen. The mixture was stirred at $100^{\circ} \mathrm{C}$ for 2 days. The crude mixture was filtered over Celite using a sintered glass filter and washed with $\mathrm{CH}_{2} \mathrm{Cl}_{2}$. The organic phase was washed with saturated $\mathrm{NH}_{4} \mathrm{Cl}(\mathrm{aq})$, dried with anhydrous $\mathrm{MgSO}_{4}$, filtered and concentrated under reduced pressure. Purification by column chromatography $\left(\mathrm{SiO}_{2}\right.$ gel, hex/AcOEt (5:1)) provided the final $\alpha$-amine ester product (3).

4.3.2. General procedure for the catalytic addition of boronic acid and derivatives to 2,2-bis(4-methylphenylsulfonamido)acetate (2) using a Rh catalyst ${ }^{34}$ (Tables 2 and 3). 1,4-Dioxane $(2.0 \mathrm{ml})$ was added to a round-bottom flask containing $[\mathrm{Rh}(\mathrm{COD}) \mathrm{OH}]_{2}(1.5 \mathrm{~mol} \%),(R, R)-$ DeguPhos (3.3 mol \%), 2,2-bis(4-methylphenylsulfonamido)acetate (2) $(0.12 \mathrm{mmol})$, organoboron reagent $(0.4 \mathrm{mmol})$ and $\mathrm{KHF}_{2}$ $(0.8 \mathrm{mmol})$ under nitrogen. The mixture was stirred at $100{ }^{\circ} \mathrm{C}$ for 1 day. The solvent was evaporated under reduced pressure and the crude mixture purified by column chromatography $\left(\mathrm{SiO}_{2}\right.$ gel, hex/ AcOEt (5:1)) providing the final $\alpha$-amine ester product (3).

4.3.3. Ethyl 2-(4-methylphenylsulfonamido)-2-phenylacetate (3a). ${ }^{35}$ White solid (38\% yield). Mp: 88.6-90.4 ${ }^{\circ} \mathrm{C}$. ${ }^{1} \mathrm{H}$ NMR $\left(400 \mathrm{MHz}, \mathrm{CDCl}_{3}\right) \delta: 1.09$ (dd, $\left.\mathrm{CH}_{3}, 3 \mathrm{H}\right), 2.38$ (s, $\left.\mathrm{CH}_{3} \mathrm{Ts}, 3 \mathrm{H}\right)$, 3.92-4.08 (m, $\left.\mathrm{CH}_{2}, 2 \mathrm{H}\right), 5.02-5.04(\mathrm{~d}, \mathrm{CH}, 1 \mathrm{H}), 5.69-5.71(\mathrm{~m}, \mathrm{NH}$, $1 \mathrm{H}), 7.18-7.20(\mathrm{Ar}, 2 \mathrm{H}), 7.22-7.26(\mathrm{Ar}, 5 \mathrm{H}), 7.62-7.64(\mathrm{Ar}, 2 \mathrm{H}) .{ }^{13} \mathrm{C}$ NMR $\left(100 \mathrm{MHz} \mathrm{CDCl}_{3}\right) \delta: 13.96,21.61,59.48,62.35,127.10,127.21$, 127.34, 128.63, 128.89, 129.55, 129.58, 129.61, 135.63, 137.09, 138.63, 143.64, 170.19. MS (ESI-TOF) $m / z: 334.12(\mathrm{M}+1)$. HPLC [Chiralcel OD-H column, hexane/2-propanol (95:5), flow rate $=1.0 \mathrm{ml} / \mathrm{min}$, $\lambda=230 \mathrm{~nm}]: t_{R}=20.1$ and $21.9 \mathrm{~min}$.

4.3.4. Ethyl 2-(4-methylphenylsulfonamido)-2-(naphthalen-2-yl)acetate (3b). ${ }^{35,36}$ Yellow solid (28\% yield). Mp: $115.0-116.7{ }^{\circ} \mathrm{C} .{ }^{1} \mathrm{H}$ $\operatorname{NMR}\left(400 \mathrm{MHz}, \mathrm{CDCl}_{3}\right) \delta: 1.11\left(\mathrm{dd}, \mathrm{CH}_{3}, 3 \mathrm{H}\right), 2.26\left(\mathrm{~s}, \mathrm{CH}_{3} \mathrm{Ts}, 3 \mathrm{H}\right)$, 4.16-4.31 ( $\left.\mathrm{m}, \mathrm{CH}_{2}, 2 \mathrm{H}\right), 5.22-5.23(\mathrm{~d}, \mathrm{CH}, 1 \mathrm{H}), 5.86-5.88(\mathrm{~d}, \mathrm{NH}$, 1H), 7.14-7.15 (Ar, 2H), 7.29-7.34 (Ar, 2H), 7.40-7.44 (Ar, 1H), 7.48-7.49 (Ar, 1H), 7.73-7.77 (Ar, 3H), 7.84-7.86 (Ar, 2H). ${ }^{13} \mathrm{C} N M R$ $\left(100 \mathrm{MHz}, \mathrm{CDCl}_{3}\right) \delta: 14.08,22.97,59.64,62.34,109.60,117.93$, 123.67, 124.26, 126.04, 126.46, 126.60, 127.88, 128.57, 129.02, 129.49, $129.92,133.43,134.73,135.85,153.60,173.79$. MS (ESI-TOF) $m / z$ : $384.13(\mathrm{M}+1)$. HPLC analysis not carried out.

4.3.5. Ethyl 2-(2-methoxyphenyl)-2-(4-methylphenylsulfonamido) acetate $(3 \mathrm{c})$. White solid (58\% yield). ${ }^{1} \mathrm{H}$ NMR (400 $\left.\mathrm{MHz} \mathrm{CDCl}_{3}\right) \delta$ : 1.09 (dd, $\left.\mathrm{CH}_{3}, 3 \mathrm{H}\right), 2.36$ (s, $\left.\mathrm{CH}_{3} \mathrm{Ts}, 3 \mathrm{H}\right), 3.92\left(\mathrm{~s}, \mathrm{OCH}_{3}, 3 \mathrm{H}\right), 4.02-4.24$ $\left(\mathrm{m}, \mathrm{CH}_{2}, 2 \mathrm{H}\right), 5.27-5.29(\mathrm{~d}, \mathrm{CH}, 1 \mathrm{H}), 5.93-5.95(\mathrm{~d}, \mathrm{NH}, 1 \mathrm{H})$, 6.91-6.93 (Ar, 2H), 7.02-7.06 (Ar, 2H), 7.44-7.47 (Ar, 2H), 7.85-7.87 $(\mathrm{Ar}, 2 \mathrm{H}) .{ }^{13} \mathrm{C}$ NMR $\left(100 \mathrm{MHz}, \mathrm{CDCl}_{3}\right) \delta: 14.06,21.26,55.62,61.72$, 70.60, 110.10, 111.23, 120.97, 121.39, 127.20, 127.49, 129.41, 130.01, 130.27, 132.70, 133.11, 136.98, 164.64. MS (ESI-TOF) $\mathrm{m} / \mathrm{z}: 364.13$ $(\mathrm{M}+1)$. HPLC analysis not carried out.

4.3.6. Ethyl 2-(4-chlorophenyl)-2-(4-methylphenylsulfonamido)acetate (3d). ${ }^{35 a, 36}$ Yellow oil (35\% yield). Mp: $86.8-89.0{ }^{\circ} \mathrm{C} .{ }^{1} \mathrm{H}$ NMR $\left(400 \mathrm{MHz}, \mathrm{CDCl}_{3}\right) \delta: 1.10\left(\mathrm{~m}, \mathrm{CH}_{3}, 3 \mathrm{H}\right), 2.39\left(\mathrm{~s}, \mathrm{CH}_{3} \mathrm{Ts}, 3 \mathrm{H}\right), 3.97-4.10$ $\left(\mathrm{m}, \mathrm{CH}_{2}, 2 \mathrm{H}\right), 4.99-5.01(\mathrm{~d}, \mathrm{CH}, 1 \mathrm{H}), 5.77-5.79(\mathrm{~d}, \mathrm{NH}, 1 \mathrm{H})$, 6.75-6.77 (Ar, 2H), 7.14-7.22 (Ar, 2H), 7.32-7.38 (Ar, 2H), 7.59-7.61 (Ar, 2H). ${ }^{13} \mathrm{C}$ NMR $\left(100 \mathrm{MHz}, \mathrm{CDCl}_{3}\right) \delta: 14.07,21.76,58.73,62.86$, $116.80,127.20,127.92,128.53,128.98,129.50,129,59,133.94,134.64$, 136.86, 143.92, 154.42, 169.75. MS (ESI-TOF) $m / z: 368.08(\mathrm{M}+1)$. HPLC analysis not carried out.

4.3.7. Ethyl 2-(3-methoxyphenyl)-2-(4-methylphenylsulfonamido) acetate (3e). Yellow oil (56\% yield). ${ }^{1} \mathrm{H}$ NMR $\left(400 \mathrm{MHz}, \mathrm{CDCl}_{3}\right) \delta$ :
1.10 (dd, $\left.\mathrm{CH}_{3}, 3 \mathrm{H}\right), 2.38$ (s, $\left.\mathrm{CH}_{3} \mathrm{Ts}, 3 \mathrm{H}\right), 3.72\left(\mathrm{~s}, \mathrm{OCH}_{3}, 3 \mathrm{H}\right), 3.93-4.11$ $\left(\mathrm{m}, \mathrm{CH}_{2}, 2 \mathrm{H}\right), 5.02(\mathrm{~d}, \mathrm{CH}, 1 \mathrm{H}), 5.72-5.74(\mathrm{~d}, \mathrm{NH}, 1 \mathrm{H}), 6.72(\mathrm{Ar}, 1 \mathrm{H})$, 6.77-6.83 (Ar, 2H), 7.14-7.20 (Ar, 3H), 7.61-7.64 (Ar, 2H). ${ }^{13} \mathrm{C} N M R$ $\left(100 \mathrm{MHz}, \mathrm{CDCl}_{3}\right) \delta: 13.97,21.60,55.32,59.44,62.38,112.54,114.41$, $119.56,127.24,128.48,129.42,129.58,129.92,136.83,137.12,143.62$, 159.90, 170.10. MS (ESI-TOF) $m / z: 364.14(\mathrm{M}+1)$. HPLC analysis not carried out.

4.3.8. Ethyl 2-(3-acetylphenyl)-2-(4-methylphenylsulfonamido)acetate (3f). White solid (61\% yield). ${ }^{1} \mathrm{H}$ NMR $(400 \mathrm{MHz}$, $\left.\mathrm{CDCl}_{3}+\mathrm{DMSO}-d_{6}\right) \delta: 0.97\left(\mathrm{~m}, \mathrm{CH}_{3}, 3 \mathrm{H}\right), 2.40\left(\mathrm{~s}, \mathrm{CH}_{3}, 3 \mathrm{H}\right), 2.49(\mathrm{~s}$, $\left.\mathrm{CH}_{3} \mathrm{Ts}, 3 \mathrm{H}\right), 3.81-3.86\left(\mathrm{~m}, \mathrm{CH}_{2}, 2 \mathrm{H}\right), 5.15-5.20(\mathrm{~s}, \mathrm{CH}, 1 \mathrm{H})$, 5.90-6.05 (d, NH, 1H), 7.05-7.07 (Ar, 2H), 7.19-7.22 (Ar, 2H), 7.33-7.38 (Ar, 1H), 7.44-7.45 (Ar, 2H), 7.71-7.73 (Ar, 1H). ${ }^{13} \mathrm{C}$ NMR $\left(100 \mathrm{MHz}, \mathrm{CDCl}_{3}+\mathrm{DMSO}-d_{6}\right) \delta: 13.64,21.32,29.59,62.22,63.36$, 126.17, 126.84, 127.01, 128.54, 129.22, 129.26, 129.33, 129.41, 129.78, 132.96, 137.92, 143.24, 167.47, 197.89. MS (ESI-TOF) m/z: 376.12 $(\mathrm{M}+1)$. HPLC analysis not carried out.

4.3.9. Ethyl 2-(4-methylphenylsulfonamido)-2-(naphthalen-1-yl)acetate (3g). Yellow solid (79\% yield). ${ }^{1} \mathrm{H}$ NMR (400 $\mathrm{MHz}$, $\left.\mathrm{CDCl}_{3}+\mathrm{DMSO}-d_{6}\right) \delta: 1.15\left(\mathrm{~m}, \mathrm{CH}_{3}, 3 \mathrm{H}\right), 2.31\left(\mathrm{~s}, \mathrm{CH}_{3} \mathrm{Ts}, 3 \mathrm{H}\right)$, $3.98-4.25\left(\mathrm{~m}, \mathrm{CH}_{2}, 2 \mathrm{H}\right), 5.74(\mathrm{~s}, \mathrm{CH}, 1 \mathrm{H}), 5.81(\mathrm{~s}, \mathrm{NH}, 1 \mathrm{H}), 7.48-7.53$ (Ar, 2H), 7.57-7.61 (Ar, 4H), 7.91-7.98 (Ar, 2H), 8.11-8.18 (Ar, 2H), 8.35-8.41 (Ar, 1H). ${ }^{13} \mathrm{C}$ NMR (100 MHz, CDCl $\left.3+\mathrm{DMSO}_{3} \mathrm{~d}_{6}\right) \delta: 14.13$, 21.67, 57.25, 62.63, 125.16, 125.30, 125.95, 126.60, 127.01, 127.28, $128.05,128.96,129.85,130.96,132.55,133.55,137.76,139.20,143.75$, 149.27, 157.94. MS (ESI-TOF) $m / z: 384.14(\mathrm{M}+1)$. HPLC analysis not carried out.

4.3.10. Ethyl 2-(4-fluorophenyl)-2-(4-methylphenylsulfonamido)acetate (3h). ${ }^{35}$ White solid (45\% yield). ${ }^{1} \mathrm{H}$ NMR $(400 \mathrm{MHz}$, $\left.\mathrm{CDCl}_{3}+\mathrm{DMSO}-d_{6}\right) \delta: 0.92-0.97\left(\mathrm{~m}, \mathrm{CH}_{3}, 3 \mathrm{H}\right), 2.31\left(\mathrm{~s}, \mathrm{CH}_{3} \mathrm{Ts}, 3 \mathrm{H}\right)$, 3.77-3.93 (m, $\left.\mathrm{CH}_{2}, 2 \mathrm{H}\right), 5.12-5.17(\mathrm{~d}, \mathrm{CH}, 1 \mathrm{H}), 6.03(\mathrm{~s}, \mathrm{NH}, 1 \mathrm{H})$, 7.13-7.19 (Ar, 4H), 7.39-7.53 (Ar, 1H), 7.57-7.59 (Ar, 2H), 7.69-7.72 $(\mathrm{Ar}, 1 \mathrm{H}) .{ }^{13} \mathrm{C}$ NMR $\left(100 \mathrm{MHz}, \mathrm{CDCl}_{3}+\mathrm{DMSO}_{-} d_{6}\right) \delta: 13.60,21.33$, 63.00, 66.81, 115.26, 115.42, 125.71, 126.92, 128.20, 128.72, 129.09, $137.08,137.86,138.08,140.34,142.94,167.23$. MS (ESI-TOF) $m / z$ : $352.11(\mathrm{M}+1)$. HPLC analysis not carried out.

4.3.11. Ethyl 2-(3-(benzyloxy)phenyl)-2-(4-methylphenylsulfona mido)acetate (3i). Colourless oil (30\% yield). ${ }^{1} \mathrm{H}$ NMR $(400 \mathrm{MHz}$, $\left.\mathrm{CDCl}_{3}\right) \delta: 1.10\left(\mathrm{dd}, \mathrm{CH}_{3}, 3 \mathrm{H}\right), 2.36\left(\mathrm{~s}, \mathrm{CH}_{3} \mathrm{Ts}, 3 \mathrm{H}\right), 3.94-4.07\left(\mathrm{~m}, \mathrm{CH}_{2}\right.$, $2 \mathrm{H}), 4.95-4.96\left(\mathrm{~d}, \mathrm{CH}_{2}, 1 \mathrm{H}\right), 5.07\left(\mathrm{~d}, \mathrm{CH}_{2}, 1 \mathrm{H}\right), 5.12-5.14(\mathrm{~d}, \mathrm{CH}, 1 \mathrm{H})$, 5.74-5.76 (d, NH, 1H), 6.83-6.88 (Ar, 2H), 7.18-7.20 (Ar, 2H), 7.33-7.45 (Ar, 7H), 7.62-7.64 (Ar, 2H). ${ }^{13} \mathrm{C} \mathrm{NMR}\left(100 \mathrm{MHz}, \mathrm{CDCl}_{3}\right) \delta$ : $14.06,22.66,59.33,62.36,69.43,113.02,113.30,115.07,115.25$, 119.34, 119.86, 127.34, 127.60, 128.64, 128.19, 128.73, 129.58, 136.64, 137.15, 140.12, 143.61, 159.11, 173.70. MS (ESI-TOF) $\mathrm{m} / \mathrm{z}: 440.17$ $(\mathrm{M}+1)$. HPLC analysis not carried out.

4.3.12. Ethyl 2-(3-hydroxyphenyl)-2-(4-methylphenylsulfonamido) acetate (3j). White solid (31\% yield). ${ }^{1} \mathrm{H}$ NMR $(400 \mathrm{MHz}$, $\mathrm{CDCl}_{3}+$ DMSO- $\left.d_{6}\right) \delta: 0.97$ (dd, $\left.\mathrm{CH}_{3}, 3 \mathrm{H}\right), 2.33\left(\mathrm{~s}, \mathrm{CH}_{3} \mathrm{Ts}, 3 \mathrm{H}\right), 3.63(\mathrm{~s}$, $\mathrm{OH}, 1 \mathrm{H}), 3.81-3.93\left(\mathrm{~m}, \mathrm{CH}_{2}, 2 \mathrm{H}\right), 5.17-5.19(\mathrm{~d}, \mathrm{CH}, 1 \mathrm{H}), 5.87(\mathrm{~s}, \mathrm{NH}$, $1 \mathrm{H}), 6.77-6.79(\mathrm{Ar}, 2 \mathrm{H}), 7.10-7.21(\mathrm{Ar}, 4 \mathrm{H}), 7.60-7.63(\mathrm{Ar}, 2 \mathrm{H}) .{ }^{13} \mathrm{C}$ NMR (100 MHz, $\mathrm{CDCl}_{3}+$ DMSO- $\left.d_{6}\right) \delta: 13.62,21.07,63.37,66.55$, $115.45,119.39,126.16,127.00,128.36,129.33,129.35,129.44,137.86$, 140.20, 143.29, 156.94, 167.34. MS (ESI-TOF) $m / z: 350.11(\mathrm{M}+1)$. HPLC analysis not carried out.

4.3.13. Ethyl 2-(3-aminophenyl)-2-(4-methylphenylsulfonamido)acetate (3k). Orange solid (37\% yield). ${ }^{1} \mathrm{H}$ NMR (400 $\left.\mathrm{MHz}, \mathrm{CDCl}_{3}\right) \delta$ : $0.88\left(\mathrm{~m}, \mathrm{CH}_{3}, 3 \mathrm{H}\right), 2.43\left(\mathrm{~s}, \mathrm{CH}_{3} \mathrm{Ts}, 3 \mathrm{H}\right), 4.09-4.25\left(\mathrm{~m}, \mathrm{CH}_{2}+\mathrm{NH}_{2}, 4 \mathrm{H}\right)$, 4.89-4.91 (d, CH, 1H), $6.17(\mathrm{~s}, \mathrm{Ar}, 1 \mathrm{H}), 6.21-6.27(\mathrm{~d}, \mathrm{NH}, 1 \mathrm{H})$, 6.96-7.01 (Ar, 2H), 7.29-7.36 ( $\mathrm{Ar}, 2 \mathrm{H}), 7.79-7.83(\mathrm{Ar}, 2 \mathrm{H}) .{ }^{13} \mathrm{C}$ NMR 
$\left(100 \mathrm{MHz}, \mathrm{CDCl}_{3}\right) \delta: 14.26,21.65,61.02,62.03,114.09,114.39,117.88$, $126.59,129.69,130.33,137.45,137.25,139.25,143.75,145.56,172.15$. MS (ESI-TOF) $m / z$ : 287.15. HPLC analysis not carried out.

4.3.14. Ethyl 2-(4-methoxyphenyl)-2-(4-methylphenylsulfonamido) acetate (3l). White solid (39\% yield). ${ }^{1} \mathrm{H}$ NMR $\left(400 \mathrm{MHz}, \mathrm{CDCl}_{3}\right) \delta$ : 1.09 (t, $\left.\mathrm{CH}_{3}, 3 \mathrm{H}\right), 2.38$ (s, $\left.\mathrm{CH}_{3} \mathrm{Ts}, 3 \mathrm{H}\right), 3.76\left(\mathrm{~s}, \mathrm{OCH}_{3}, 3 \mathrm{H}\right), 3.89-4.05$ $\left(\mathrm{m}, \mathrm{CH}_{2}, 2 \mathrm{H}\right), 4.97-4.99(\mathrm{~d}, \mathrm{CH}, 1 \mathrm{H}), 5.71-5.73(\mathrm{~d}, \mathrm{NH}, 1 \mathrm{H})$, 6.75-6.78 (Ar, 2H), 6.88-6.90 (Ar, 1H), 7.12-7.21 (Ar, 3H), 7.32 (Ar, $1 \mathrm{H}), 7.62-7.64(\mathrm{Ar}, 1 \mathrm{H}) .{ }^{13} \mathrm{C} \mathrm{NMR}\left(100 \mathrm{MHz}, \mathrm{CDCl}_{3}\right) \delta: 14.38,22.98$, $55.45,58.73$, 62.04, 114.11, 114.25, 114.90, 126.58, 127.34, 127.61, $127.96,128.48,129.58,130.77,143.66,159.62,170.54$. MS (ESI-TOF) $m / z$ : $386.11(\mathrm{M}+1+\mathrm{Na})$. HPLC analysis was not carried out.

\subsection{Synthesis of (rac)- $\alpha$-phenylglycine (11)}

Ethyl 2-(4-methylphenylsulfonamido)-2-phenylacetate (3a) (92.3 $\mathrm{mg}, 0.3 \mathrm{mmol})$ in THF ( $5 \mathrm{ml}$ ) was stirred with an aqueous solution of $\mathrm{NaOH}(2 \mathrm{M})(1.0 \mathrm{ml}, 1.5 \mathrm{mmol})$ at $50^{\circ} \mathrm{C}$ and monitored by TLC. THF was evaporated under reduced pressure and the mixture extracted with $\mathrm{CH}_{2} \mathrm{Cl}_{2}(5 \times 10 \mathrm{ml})$. The aqueous phase was evaporated under reduced pressure and the desired $\alpha$-phenylglycine (11) was obtained as a white solid ( $>90 \%$ yield). Mp: $>300{ }^{\circ} \mathrm{C} .{ }^{1} \mathrm{H}$ NMR $\left(400 \mathrm{MHz}, \mathrm{D}_{2} \mathrm{O}\right) \delta: 4.47(\mathrm{~s}, \mathrm{CH}, 1 \mathrm{H}), 7.18-7.19(\mathrm{~m}$, Ar, 5H). ${ }^{13} \mathrm{C}$ NMR $\left(100 \mathrm{MHz}, \mathrm{D}_{2} \mathrm{O}\right) \delta: 65.63,126.35,126.58,127.50$, 128.17, 128.96, 140.86, 181.51. MS (ESI-TOF) $m / z: 158.97$ (M+).

\subsection{General procedure for the one-pot arylation-amine de- protection to afford $\alpha$-amino ester (12)}

1,4-Dioxane $(1.0 \mathrm{ml})$ was added to a round-bottom flask containing $[\mathrm{Rh}(\mathrm{COD}) \mathrm{OH}]_{2}(5 \mathrm{~mol} \%)$ and $(R, R)$-DeguPhos $(5.5 \mathrm{~mol} \%)$ and left stirring at room temperature $30 \mathrm{~min}$. 2,2-Bis(4methylphenylsulfonamido)acetate (2) $(0.19 \mathrm{mmol})$, phenylboronic acid (0.38 mmol), $3 \AA$ MS (200 mg) and 1,4-dioxane (3 ml) were added to the reaction vessel sequentially, followed by $\mathrm{NEt}_{3}$ $(0.29 \mathrm{mmol})$ and $\mathrm{K}_{2} \mathrm{CO}_{3}(1.14 \mathrm{mmol})$. The reaction was left stirring at $70{ }^{\circ} \mathrm{C}$ for 2 days. After cooling to room temperature, the crude mixture was filtered over Celite in a sintered glass filter and washed with AcOEt. The solvent was evaporated under reduced pressure and the crude product purified by column chromatography $\mathrm{SiO}_{2}$ gel, hex/AcOEt (5:1)) providing the deprotected amine product (12) as a yellow oil (72\% yield). ${ }^{1} \mathrm{H}$ NMR $\left(400 \mathrm{MHz}, \mathrm{CDCl}_{3}\right) \delta: 1.22(\mathrm{t}$, $\left.J=8 \mathrm{~Hz}, \mathrm{CH}_{3}, 3 \mathrm{H}\right), 1.26\left(\mathrm{~s}, \mathrm{NH}_{2}, 1 \mathrm{H}\right), 2.42\left(\mathrm{~s}, \mathrm{NH}_{2}, 1 \mathrm{H}\right), 4.12-4.28(\mathrm{~m}$, $\left.\mathrm{CH}_{2}, 2 \mathrm{H}\right), 5.16(\mathrm{~s}, \mathrm{CH}, 1 \mathrm{H}), 7.28-7.38(\mathrm{~m}, \mathrm{Ar}, 2 \mathrm{H}), 7.41-7.43(\mathrm{~m}, \mathrm{Ar}$, $2 \mathrm{H}), 7.79-7.81(\mathrm{~d}, \mathrm{Ar}, 1 \mathrm{H}) .{ }^{13} \mathrm{C} \mathrm{NMR}\left(100 \mathrm{MHz}, \mathrm{CDCl}_{3}\right) \delta: 14.13,62.37$, 73.01, 126.55, 128.53, 128.69, 129.81, 138.51, 143.65, 173.81. MS (ESITOF) $m / z: 203.07(\mathrm{M}+1)$. HPLC analysis not carried out.

\section{Acknowledgements}

We are grateful for the award of a PhD grant to C.S.M. (SFRH/BD/ 45132/2008) from the Fundação para a Ciência e a Tecnologia (FCT) 2010. We acknowledge LabRMN at FCT-UNL for the acquisition of the NMR spectra; the NMR spectrometers are part of the National NMR Network and were purchased within the framework of the National Programme for Scientific Re-equipment (contract REDE/ 1517/RMN/2005), with funds from POCI 2010 (FEDER) and FCT. The University of Vigo (Spain) is gratefully acknowledgement for MS analysis.

\section{Supplementary data}

Supplementary data related to this article can be found at http:// dx.doi.org/10.1016/j.tet.2013.09.053.

\section{References and notes}

1. (a) Barrett, G. C.; Telmore, D. Amino Acids and Peptides; Cambridge University, 2004; (b) Hughes, A. B.; Amino Acids, Peptides and Proteins in Organic Chemistry, 1st ed.; Wiley-VCH, 2009, Vol. 1; (c) Loscha, K. V.; Herlt, A. J.; Qi, R.; Huber, T.; Ozawa, K.; Otting, G. Angew. Chem., Int. Ed. 2012, 51, 2243-2246; (d) Shen, B.; Xiang, Z.; Miller, B.; Louie, G.; Wang, W.; Noel, J. P.; Gage, F. H.; Wang, L. Stem Cells 2011, 29, 1231-1240; (e) Unnatural Amino Acids: Methods and Protocols Methods in Molecular Biology; Pollegioni, L., Servi, S., Eds.; Humana: 2012; Vol. 794; (f) Chin, J. W. Science 2012, 336, 428-429.

2. See, for instance: (a) Huang, T.; Jander, G.; de Vos, M. Phytochemistry 2011, 72 , 1531-1537; (b) Williams, R. M. Synthesis of Optically Active R-Amino Acids In The Organic Chemistry Series; Baldwin, J. E., Ed.; Pergamon: Oxford, UK, 1989; (c) Williams, R. M.; Hendrix, J. A. Chem. Rev. 1992, 92, 889-917; (d) Córdova, A.; Notz, W.; Zhong, G.; Betancort, J. M.; Barbas, C. F. J. Am. Chem. Soc. 2002, 124, $1842-1843$

3. (a) Ma, J. S. Chem. Today 2003, 21, 65-68; (b) El-Gamel, N. E. A. J. Coord. Chem. 2010, 63, 534-543; (c) Theodoridis, G.; Konsta, G.; Bagia, C. J. Chromatogr., B 2004, 804, 43-51.

4. (a) Martens, J. Topics in Current Chemistry; Springer: Heidelberg, Germany, 1984 Vol. 125, pp 167-246; (b) Nájera, C.; Sansano, J. M. Chem. Rev. 2007, 107, 4584-4671; (c) Cativiela, C.; Díaz-de-Villegas, M. D. Tetrahedron: Asymmetry 2007, 18, 569-623; (d) O'Donnell, M. J. Acc. Chem. Res. 2004, 37, 506-517; (e) Michaux, J.; Niel, G.; Campagne, J. M. Chem. Soc. Rev. 2009, 38, 2093-2116; (f) Perdih, A.; Dolenc, M. S. Curr. Org. Chem. 2007, 11, 801-832; (g) Müller, R. Goesmann, H.; Waldmann, H. Angew. Chem., Int. Ed. 1999, 38, 184-187; (h) Xua, L.-W.; Lu, Y. Org. Biomol. Chem. 2008, 6, 2047-2053; (i) Jarvo, E.; Miller, S. J Tetrahedron 2002, 58, 2481-2495; (j) Qu, Z.-R.; Zhao, H.; Wang, X.-S.; Li, Y.-H.; Song, Y.-M.; Liu, Y.-J.; Ye, Q.; Xiong, R.-G.; Abrahams, B. F.; Xue, Z.-L.; You, X.-Z Inorg. Chem. 2003, 42, 7710-7712.

5. Schoemaker, H. E.; Boesten, W. H. J.; Kaptein, B.; Hermes, H. F. M.; Sonke, T.; Broxterman, Q. B.; van den Tweel, W. J. J.; Kamphuis, J. Pure Appl. Chem. 1992 $64,1171-1175$.

6. (a) Tolman, V.; Simek, P. J. Fluorine Chem. 2000, 107, 4584-4671; (b) Kesslin, G. Kelly, K. W. In Resolution of Racemic Mandelic Acid, Key Fries, US4322548, USA, 1982.

7. For some recent examples, see: (a) Saravanan, S.; Sadhukhan, A.; Khan, N. H.; Kureshy, R. I.; Abdi, S. H. R.; Bajaj, H. C. J. Org. Chem. 2012, 77, 4375-4384; (b) Pathare, S. P.; Akamanchi, K. G. Tetrahedron Lett. 2012, 53, 871-875; (c) Wang, J.; Liu, X.; Feng, X. Chem. Rev. 2011, 111, 6947-6983.

8. Knowles, W. S. Adv. Synth. Catal. 2003, 345, 3-13.

9. Corey, E. J.; Link, J. O. J. Am. Chem. Soc. 1992, 114, 1906-1908.

10. Taggi, A. E.: Hafez, A. M.; Lectka, T. Acc. Chem. Res. 2003, 36, 10-19.

11. Hagiwara, E.; Fujii, A.; Sodeoka, M. J. Am. Chem. Soc. 1998, 120, 2474-2475.

12. Kobayashi, S.; Matsubara, R.; Kitagawam, H. Org. Lett. 2002, 4, 143-145.

13. Ferraris, D.; Young, B.; Cox, C.; Dudding, T.; Drury, W. J., III; Ryzhkov, L.; Taggi, A. E.; Lectka, T. J. Am. Chem. Soc. 2002, 124, 67-77.

14. (a) Saaby, S.; Fang, X.; Gathergood, N.; Jorgensen, K. A. Angew. Chem., Int. Ed. 2000, 39, 4114-4116; (b) Saaby, S.; Bayon, P.; Aburel, P. S.; Jorgensen, K. A. J. Org. Chem. 2001, 67, 4352-4361.

15. Johannsen, M. Chem. Commun. 1999, 2233-2234.

16. (a) Marques, C. S.; Burke, A. J. Eur. J. Org. Chem. 2010, 1639-1643; (b) Marques, C. S.; Burke, A. J. Chem CatChem 2011, 3, 635-645; (c) Marques, C. S.; Burke, A. J. Eur. J. Org. Chem. 2012, 4232-4239; (d) Marques, C. S.; Burke, A. J. Tetrahedron 2012, 68, 7211-7216; (e) Marques, C. S.; Burke, A. J. Tetrahedron: Asymmetry 2013, 24, 628-632.

17. Ferraris, D.; Young, B.; Dudding, T.; Drury, W. J., III; Lectka, T. Tetrahedron 1999 $55,8869-8882$

18. Johansson, C. C. C.; Colacot, T. J. Angew. Chem., Int. Ed. 2010, 49, 676-707.

19. (a) Buncel, E.; Dust, J. M.; Terrier, F. Chem. Rev. 1995, 95, 2261-2280; (b) Selvakumar, N.; Reddy, B. Y.; Kumar, G.-S.; Iqbal, J. Tetrahedron Lett. 2001, 42, 8395-8398.

20. Culkin, D. A.; Hartwig, J. F. Acc. Chem. Res. 2003, 36, 234-245.

21. (a) Zhou, J. S. Synlett 2012, 1-5; (b) Arya, P.; Qin, H. Tetrahedron 2009, 56 , 917-947.

22. Ma, G.-N.; Zhang, T.; Shi, M. Org. Lett. 2009, 11, 875-878.

23. Hall, D. G. Boronic Acids; Wiley-VCH: Weinheim, Germany, 2005

24. Dai, H.; Lu, X. Tetrahedron Lett. 2009, 50, 3478-3481.

25. For catalytic imine alkylations with aliphatic boronic acids see: (a) Yu, X.; Liebeskind, L. S. J. Org. Chem. 2004, 69, 3554-3557; (b) Cyrański, M. K.; Jezierska, A.; Klimentowska, P.; Panek, J. J.; Zukowska, G. Z.; Sporzyński, A. J. Chem. Phys. 2008, 128, 124512-1-124512-9; (c) Kuriyama, M.; Shimazawa, R.; Shirai, R. J. Org. Chem. 2008, 73, 1597-1600.

26. (a) Moreno-Manas, M.; Pérez, M.; Pleixats, R. J. Org. Chem. 1996, 61, 2346-2351; (b) Wong, M. S.; Zhang, X. L. Tetrahedron Lett. 2001, 42, 4087-4089.

27. Kuivila, H. G.; Reuwer, J. F., Jr.; Mangravite, J. A. Can. J. Chem. 1963, 41, 3081-3090.

28. For some examples see: (a) Hayashi, T.; Yamasaki, K. Chem. Rev. 2003, 103 2829-2844; (b) Fagnou, K.; Lautens, M. Chem. Rev. 2003, 103, 169-196; (c) Tian, P.; Dong, H.-Q.; Lin, G.-Q. ACS Catal. 2012, 2, 95-119; (d) Menard, F.; Chapman, T. M.; Dockendorff, C.; Lautens, M. Org. Lett. 2006, 8, 4569-4572; (e) Martina, S. L. X.; Minnaard, A. J.; Hessen, B.; Feringa, B. L. Tetrahedron Lett. 2005, 46, 7159-7163; (f) Nakagawa, H.; Rech, J. C.; Sindelar, R. W.; Ellman, J. A. Org. Lett. 2007, 9, 5155-5157.

29. Shintani, R.; Takeda, M.; Tsuji, T.; Hayashi, T. J. Am. Chem. Soc. 2010, 132, $13168-13169$. 
30. (a) Yang, H.-Y.; Xu, M.-H. Chem. Commun. 2010, 9223-9922; (b) Shao, C.; Yu, H.J.; Wu, N.-Y.; Feng, C.-G.; Lin, G.-Q. Org. Lett. 2010, 12, 3820-3823; (c) Wang, Z.Q.; Feng, C.-G.; Zhang, S.-S.; Xu, M.-H.; Lin, G.-Q. Angew. Chem., Int. Ed. 2010, 49, 5780-5783.

31. Crampton, R. H.; Fox, M.; Woodward, S. Tetrahedron: Asymmetry 2013, 24, 599-605.

32. Bommarius, A. S. Schwarm, M.: Drauz, K. J. Mol Catal. B: Enzym. 1998, 5, 1-11.

33. Perrin, W. L. F. A. Purification of Laboratory Chemicals, 4th ed.; Butterworth Heinemann: Oxford, UK, 1996.
34. Adapted from literature methods, see for instance: Duan, H.-F.; Jia, Y.-X.; Wang, L.-X.; Zhou, Q.-L. Org. Lett. 2006, 8, 2567-2569.

35. (a) Dai, H. Yang, M. Lua, X. Adv Synth Catal 2008, 350, 249-253* (b) Deng O.H.; Xu, H.-W.; Yuen, A. W.-H.; Xu, Z.-J.; Che, C.-M. Org. Lett. 2008, 10, 1529-1532; (c) Oi, S.; Moro, M.; Fukuhara, H.; Kawanishi, T.; Inoue, Y. Tetrahedron 2003, 59, 4351-4361.

36. Fritz, S. P.; Moya, J. F.; Unthank, M. G.; Mcgarrigle, E. M.; Aggarwal, V. K. Synthesis 2012, 44, 1584-1590. 